\title{
The Pattern of Unique Use of Language: A Case Study in the Greeting Messages 'Konnichiwa' and 'Konbanwa' on Japanese Mobile Phone E-mail
}

\author{
Noboru Sakai ${ }^{1}$ \\ ${ }^{1}$ The Center for English as a Lingua Franca, Tamagawa University, Tokyo, Japan \\ Correspondence: Noboru Sakai, The Center for English as a Lingua Franca, Tamagawa University, Tokyo, Japan \\ Tel: 81-90-1436-5797. E-mail: noboru.sakai@uqconnect.edu.au
}

Received: March 23, 2018

Accepted: April 4, 2018

Online Published: April 9, 2018

doi:10.5539/ach.v10n2p19

URL: http://dx.doi.org/10.5539/ach.v10n2p19

\begin{abstract}
This study considers the mechanism underlying how people use unique patterns of language use as a greeting message, using Konnichiwa(こんにちは: good afternoon), and Konbanwa (こんばんは: good evening), a simple and common message appearing in Japanese mobile phone e-mail (Keitai-mail), as an example. The data corpus analyzed for this study consists of 43,295 mails for communication purposes from 60 Japanese young people. The result shows that people apply uniqueness in a limited way, and moreover their unique use of language is largely affected by the standard rules of Japanese, including sound information such that as は (ha) is pronounced /wa/ わ(wa).
\end{abstract}

Keywords: Keitai-mail, Mobile phone e-mail, Computer mediated communication (CMC), emoticons, non-textual elements, Japanese

\section{Introduction}

In the present IT era, people seem to be very familiar with CMC in their daily life, in particular in Japan, and as a striking feature of CMC, Language plays (LP), which are (in most cases) intentional use of unusual expressions, are heavily and commonly used. In Japanese Keitai-mail, several types of LP are found, as Miyake (2007) suggests (see Backgournd). LP are not solely interesting as a peculiar phenomenon; their role is not limited to matters of text. For example, Crystal (2008) introduces LP in poems composed by SMS, and mentions that the 160-word limit for SMS can be extended by the application of LP in terms of expressions. Therefore, the components and intentions of natural, but informal use of languages are important questions in the present text communications.

To answer, of the many types of discourse in Keitai-mail, this study analyses greeting messages as an example. Greeting is a short, simple, common practice in communication and people use phrases of greeting frequently in their Keitai-mail exchanges. Therefore, to allow an in-depth look at the pattern of LP applied to Keitai-mail, greeting messages are now analysed by way of example.

Linguistic and communication research focused on CMC have also been conducted and many studies illustrate the characteristics of each CMC with its unique feature (e.g., Sakai, 2018), as Zhao (2006) mentioned its significance, in different languages (e.g., Danet \& Herring, 2007). Japan, whose language has five types of scripts plus imported emoticons and original picture-based characters, is also given attention as a case study of the handling of several different script in CMC. As new media appear, new language use is introduced and discussed; however, the underlying mechanism seems too complex to encapsulate. To advance the understanding of language use and communication, this study approaches unique language use through theoretical calculation and descriptive data analysis. In addition to formal scripts in Japanese, LP make up a great amount of Japanese $\mathrm{CMC}$, including Keitai-mail, and this study investigates how these elements are used or interconnected naturally from the greeting messages こんにちは and こんばんは.

\section{Background: Japanese language}

Japanese language consists of five types of scripts: Hiragana, Katakana, Kanji, Romaji, and Arabic numerals. Hiragana characters are basic Japanese syllables which consist of forty-six characters (e.g., あ，い，う，え，お， 
か, き,く,け, こ). Katakana are scripts that are mainly used to spell foreign loan words, with the same sounds as Hiragana (e.g., ア,イ, ウ, エ, オ, カ, キ,ク,ケ,コ). Kanji are Chinese characters, and since they have been adapted to Japanese usage, Kanji are different from Chinese characters in the Chinese languages in some sense (e.g., Sunday to Saturday in Kanji can be written as 日, 月，火，水，木，金，土). Romaji are the alphabet to describe Japanese based on its sound system. Japanese writing also use Arabic numerals. In these five scripts, Hiragana and Katakana are the native Japanese writing systems, whereas the other three share some properties in its shape with language systems from some other countries. Compositions in Japanese writing are the combination of these scripts.

In Japanese CMC, several types of Language plays (unique use of language beyond the standard rule) exist. A facemark, or Kaomoji is created by using the pre-installed symbols such as $(\wedge \wedge)$ (meaning 'joy') and $\left(>_{-}<\right)$ ('sadness') (Miller, 2004), which are widely found in CMC regardless of PC or mobile phones. Emoji is pre-installed picture emoticons: for example, most frequently used Emoji in Keitai-mail are a splash of sweat $(\circ)$, shining $(\stackrel{\circ}{\circ})$, and a happy face (9) (Sakai, 2013). Similar to Emoji, Japanese Keitai-mail can also use Decome Emoji, which can be downloaded from Internet sites, and can be added to Keitai-mail. In theory, the number of Decome Emoji are unlimited.

Moreover, pre-installed symbols in font sets such as or $\supset$ are inserted as a part of text. In other cases, some Kanji (Chinese character) are used beyond the standard rules, to express writers' feelings (in many cases disclosed by parenthesis) (Hanai \& Oguchi, 2008).

With LP above discussions, Miyake (2007) summarizes extra-textual elements found in Japanese CMC, in particular Japanese mobile-email (Figure 1).

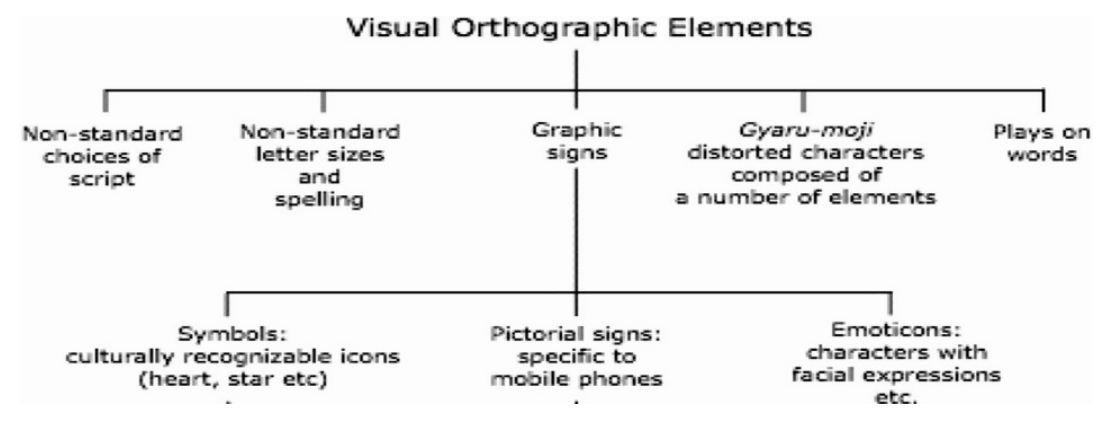

Figure 1. Extra-textual-elements in Japanese mobile e-mail

Source: Miyake, 2007, p. 62.

In addition to formal scripts in Japanese, LP occupy a great amount of Japanese CMC, including Keitai-mail, and this study investigate how these elements are used or interconnected naturally from a greeting messages of こんにちは and こんばんは.

\section{Methods}

This study analyzes the corpus from raw data of communication practices appeared in Keitai-mail the researchers gained through field work. In detail, this study analyses 43,295 Keitai-mail for communication purposes collected from 60 Japanese young people (aged 18 to 30, ratio of male to female is 1:1. i.e, 30 male participants and 30 female participants) during May 2009 to January 2010. ${ }^{1}$ The participants use mobile phones sold by the three major Japanese Keitai companies: NTT Docomo, Softbank and au, and the numbers of participants using each Keitai company are as follows: Docomo 28, SoftBank 11, and au 21. Keitai-mail are collected by Keitai-mail backup software Keitai-master $M X$ (ver 4.5) (Jungle Inc., 2009), with selection of participants which Keitai-mail could offer. Because of specification matters, Decome Emoji stored in au mobiles cannot be collected.

Of the many types of discourse in Keitai-mail, this study analyses greeting messages as an example. Greeting is a short, simple, common practice in communication and people use phrases of greeting frequently in their Keitai-mail exchanges. Therefore, to allow an in-depth look at the pattern of LP applied to Keitai-mail, greeting messages are now analyzed by way of example. Firstly this study intends to consider how much writers' intentions involve, by seeing the case studies to illustrate the real language use. To discuss the characteristics of 
LP, a part of expression which is necessary and follows a standard form is called base and moji additionally included as a potion are called option.

\section{Result and Discussion 1：こんにちは (Hello)}

This section discusses another greeting message，こんにちは. Table 1 shows all patterns appearing in the data. Tables 1 to 4 and Figures 2 and 3 summarise statistical information.

Table 1. Patterns of こんにちは shown in the data

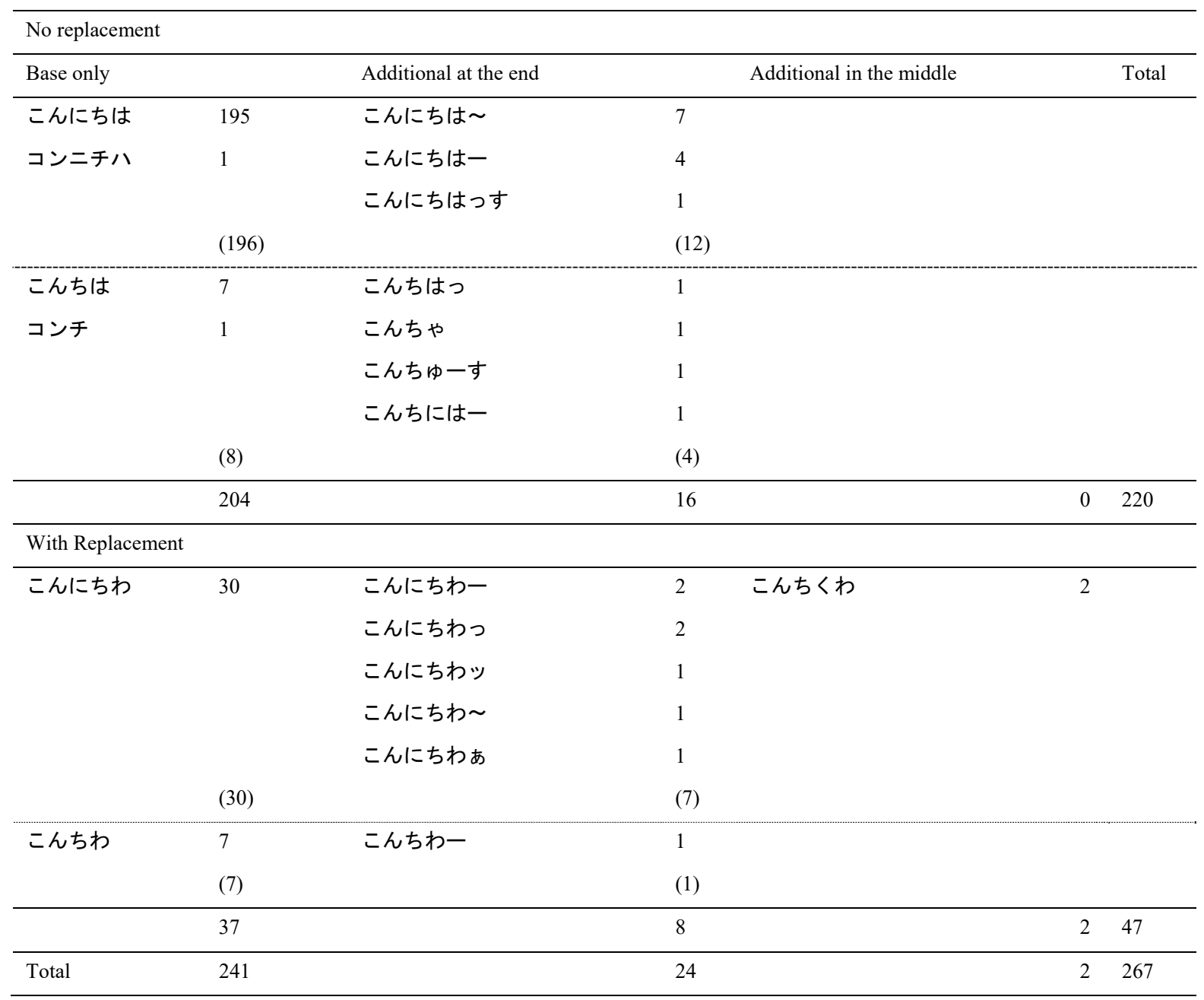

Table 2. Numbers of language plays in terms of the numbers of base syllables applied toこんにちは

\begin{tabular}{|c|c|c|c|c|c|}
\hline & $\mathrm{N}$ & W & $\mathrm{W}+\mathrm{EA}$ & $\mathrm{W}+\mathrm{MA}$ & Total \\
\hline & 5 & 196 & 15 & 0 & 211 \\
\hline \multirow[t]{4}{*}{ NR } & 4 & 7 & 1 & 0 & 8 \\
\hline & 3 & 0 & 2 & 0 & 2 \\
\hline & & 203 & 18 & 0 & $219(82.40 \%)$ \\
\hline & 5 & 30 & 6 & 0 & 36 \\
\hline \multirow[t]{3}{*}{ WR } & 4 & 7 & 1 & 2 & 10 \\
\hline & 3 & 1 & 0 & 0 & 0 \\
\hline & & 38 & 7 & 2 & $48(17.60 \%)$ \\
\hline Total & & 241 & 25 & 2 & 267 \\
\hline
\end{tabular}

Abbreviations. N: Number of base moji, W: Words with base moji.

EA: Additional moji at the end, MA: Additional moji between the moji of base. 


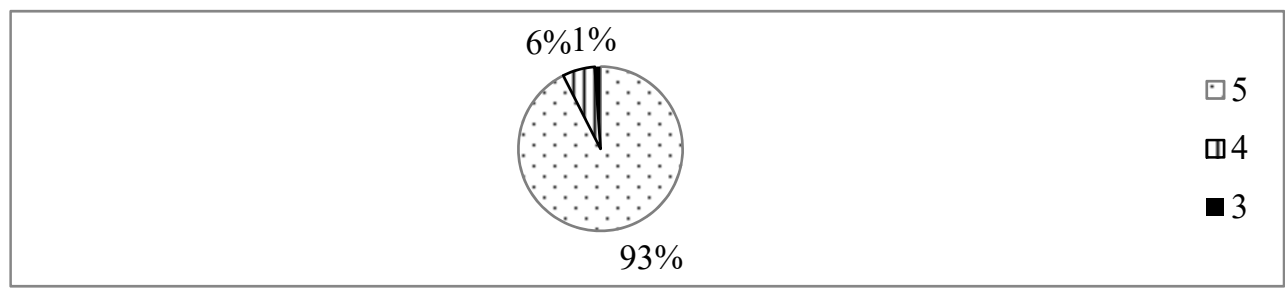

Figure 2. Frequency of words in terms of the number of use in base syllables applied to こんにちは NR: No replacement, WR: Words including replacements in their base syllables.

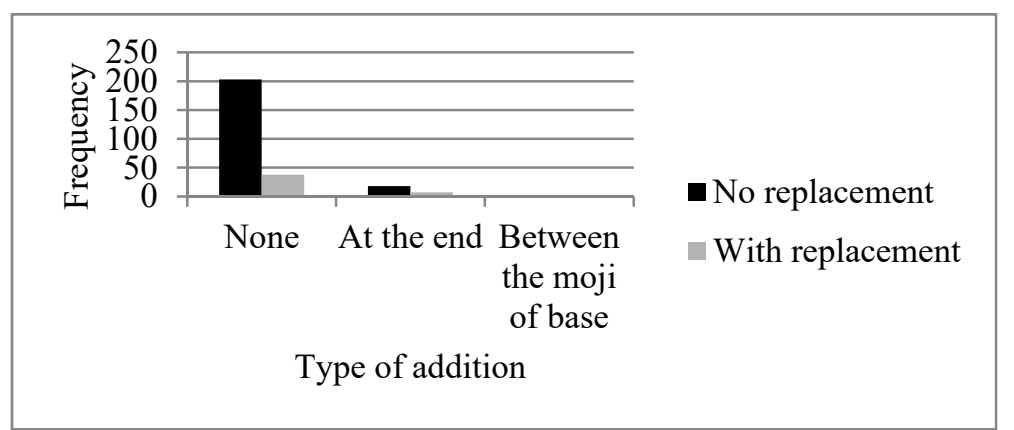

Figure 3. Frequency of language plays applied to こんにちは

Table 3. Numbers of extra moji based on numbers of base syllables applied to こんにちは

\begin{tabular}{lllll}
\hline & \multicolumn{4}{c}{ Numbers of extra moji (numbers in parenthesis are total length) } \\
\hline Base syllables & 0 & 1 & 2 & 3 \\
\hline 3 & 1 & 1 & 0 & 1 \\
4 & 14 & 3 & 0 & 0 \\
5 & 227 & 19 & 1 & 0 \\
Total & 242 & 23 & 1 & 1 \\
\hline
\end{tabular}

Table 4. Total numbers of extra moji based on numbers of base syllables applied to こんにちは

\begin{tabular}{llllll}
\hline & \multicolumn{5}{c}{ Total Numbers of moji including extra moji } \\
\hline Base syllables & 3 & 4 & 5 & 6 & 7 \\
\hline 3 & 1 & 1 & 0 & 1 & 0 \\
4 & & 14 & 3 & 0 & 0 \\
5 & & & 227 & 19 & 1 \\
Total & 1 & 230 & & 20 & 1 \\
\hline
\end{tabular}

Table 5. Relationship between replacements and additions in terms of こんにちは

\begin{tabular}{llllll}
\hline & \multicolumn{5}{c}{ Addition } \\
\hline Replacement & 0 & 1 & 2 & 3 & Total \\
\hline 0 & 204 & 15 & 0 & 1 & 220 \\
1 & 39 & 7 & 1 & 0 & 47 \\
Total & 243 & 22 & 1 & 1 & 267 \\
\hline
\end{tabular}

Table 6. Total numbers of replacements and additions applied to こんにちは

\begin{tabular}{lll}
\hline Number of language play & Frequency & $\%$ \\
\hline 0 & 204 & $76.404 \%$ \\
1 & 54 & $20.225 \%$ \\
2 & 8 & $2.996 \%$ \\
3 & 1 & $0.375 \%$ \\
\hline
\end{tabular}


Through this statistical information, we can see the same tendency, that participants mainly choose a very simple form as their original one (a full five syllables of こんにちは without using LP), and they also use some LP in a simple manner.

Comparing おはよう (good morning) and こんにちは, while the former uses additional moji more than replacements (おはよーう - おはよお), the latter shows the opposite pattern. This can be explained thus: to use replacements in おはよう requires a certain level of incongruity, but to replace は with わ(こんにちは toこんにちわ) seems more natural since は in こんにちは is pronounced /wa/, i.e., it is equivalent to the sound of わ. This result accords with the prediction from the previous section as well and affords further evidence for the prediction of phonological dependency in composing a written text.

As a base syllable reduction form, the participants use こんちは, which omits a syllable in the middle, rather than こんにち, which omits a syllable at the end in the same way as おはよ. The reason for こんちは as a word pattern is simply that this is a reflection of the spoken form of modern Japanese in Keitai-mail texts and is doubtless natural. However, it is interesting that there is no こんにち pattern in the data. This indicates that even though LP is a creative act with a theoretically infinite potential to form patterns, people tend to create patterns based on common usage of language (phonetic contraction). In this case study, the reflection of phonetic contraction is only about $7.5 \%(20 / 267)$.

The case study of こんにちは gives supporting evidence for the predictions in the previous studies, and also tells us that even though LP are a way to impart some form of uniqueness which violates a standard rule, this also depends on relative maintenance of the naturalness of the standard rules: the limitation of LP is that they cannot violate the standard rules too much, in order to keep the original meanings of each word.

\section{Result and Discussion 2:こんばんは (Good Evening)}

Table 7 illustrates the patterns found for こんばんは. The table shows basically the same tendency as the case of こんにちは. In particular, the replacement of は with わ occurs to a certain extent, as shown by Figure 4 showing a similar shape to Figure 5 .

Table 7. Patterns of こんばんは shown in Keitai-mail in terms of type of syllable

\begin{tabular}{|c|c|c|c|c|c|c|}
\hline \multicolumn{7}{|c|}{ No replacement } \\
\hline Base only & & Additional at the end & & Additional in the middle & & Total \\
\hline こんばんは & 272 & こんばんは〜 & 17 & こんば〜ん & 1 & \\
\hline \multirow[t]{6}{*}{ こんばん } & 1 & こんばんは一 & 5 & おこんばんは & 1 & \\
\hline & & こんばんはあ & 2 & & & \\
\hline & & こんばんはっ & 1 & & & \\
\hline & & こんばんはッ & 1 & & & \\
\hline & & こんばー & 1 & & & \\
\hline & (273) & & $(29)$ & & (2) & 292 \\
\hline \multirow[t]{4}{*}{ 今晚は } & 15 & 今晚は〜 & 3 & & & \\
\hline & & 今晚は一 & 1 & & & \\
\hline & $(15)$ & & $(4)$ & & $(0)$ & 19 \\
\hline & 288 & & 32 & & 2 & 321 \\
\hline \multicolumn{7}{|c|}{ With Replacement } \\
\hline こんばんわ & 48 & こんばんわ〜 & 3 & & & \\
\hline コンバンワ & 5 & こんばんわあ & 1 & & & \\
\hline こんばんわ & 4 & こんばんわッ & 1 & & & \\
\hline \multirow[t]{4}{*}{ こんばんみ } & 5 & こんばんみ〜 & 1 & & & \\
\hline & & こんばんみー & 2 & & & \\
\hline & & こんばんみい & 1 & & & \\
\hline & (62) & & (9) & & $(0)$ & 71 \\
\hline 今晚わ & 3 & 今晚わんこそば & 1 & & & \\
\hline 今晚和 & 1 & & & & & \\
\hline \multirow[t]{3}{*}{ 今晚わ } & 2 & & & & & \\
\hline & (6) & & $(1)$ & & $(0)$ & 7 \\
\hline & 68 & & 10 & & 0 & 78 \\
\hline Total & 356 & & 41 & & 2 & 399 \\
\hline
\end{tabular}

Note. The number in parenthesis shows the total number in each subcategory. 
For more detailed discussion, compared with the case of こんにちは,こんばんは (good evening) includes a significantly different pattern: こんばんは can be written in Kanji 今晚は. The proportion of the Kanji form is small in the overall patterns. As for the two patterns, if the occurrence is illustrated based on percentile (Figure 5), both patterns show the same tendency as the tendency as a whole shown in Figure 4. This result indicates that the overall tendency towards choosing a simple pattern is not affected by the type of moji.

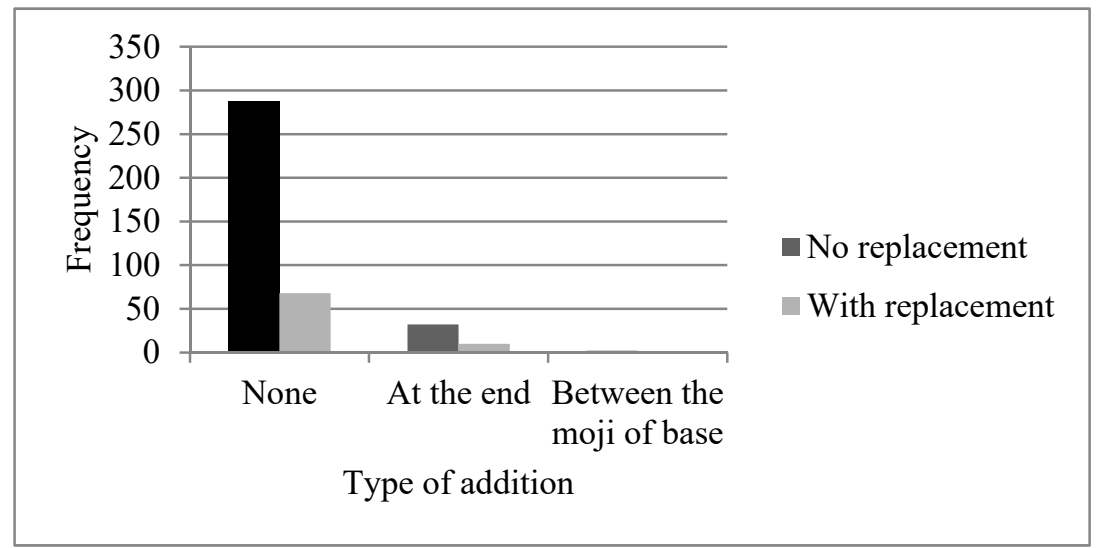

Figure 4. Proportion of language plays in こんばんは

Abbreviations. W: Words with base moji, EA: Additional moji at the end

MA: Additional moji between the moji of base, NR: No replacement

WR: Words including replacements in their base syllables

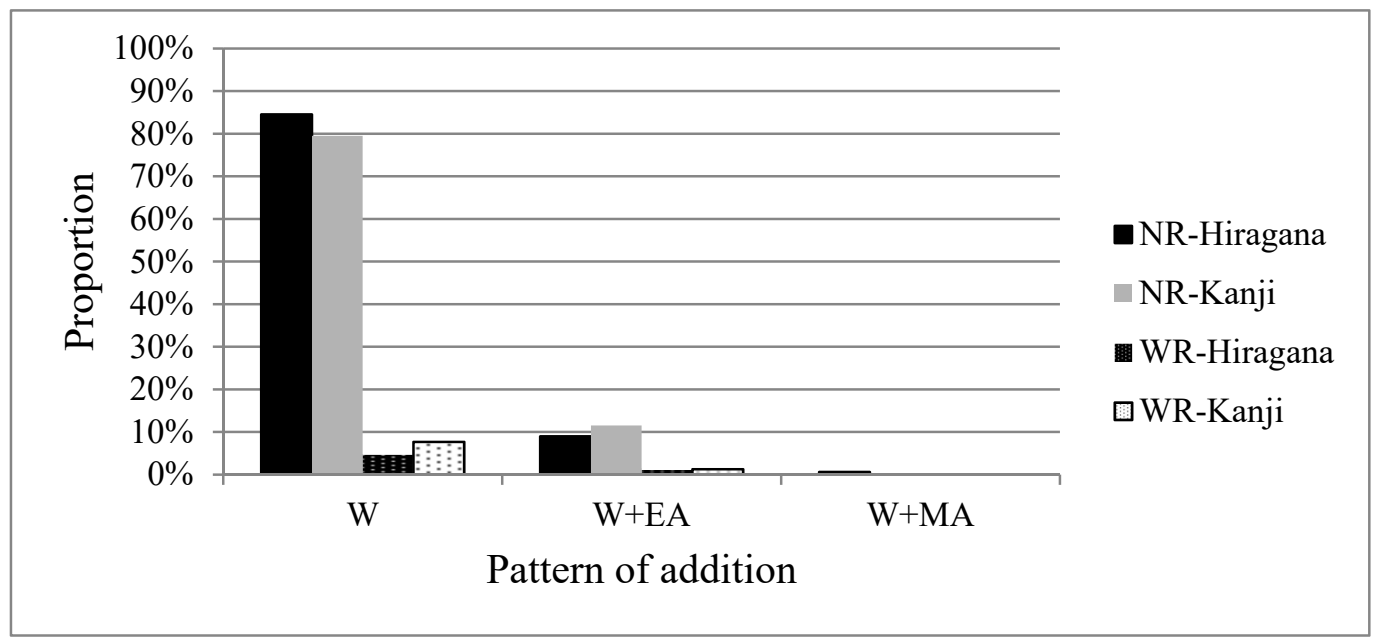

Figure 5. Proportion of language plays in terms of type of moji (percentile of each type)

In terms of the number of moji, Table 8 summarises the proportion of occurrence based on the number of moji compared with the standard form. For example，こんばん consists of four moji, and since the standard form of こんばんは is a five-moji word, so こんばん is categorised as N-1. Similarly, 今晚わんこそば, which is a unique pattern from 今晚は, consists of seven moji, and its original 今晚はhas three moji, so 今晚わんこそ ば is counted as N+4 category (Figure 6 illustrates the percentile of each pattern).

These summaries suggest that, even though a word may exhibit several patterns, the distribution of each pattern centralises at the number of the standard form. Moreover, as with the previous case study, people usually employ minimal addition and subtraction to create a LP. In the case of 今晚わんこそば, one Kanji form has four additional moji as shown. Here, わんこそば (a type of Soba noodle) is a word and the sequence of four additional moji in this expression is just a case of use of an additional word instead of adding four separate moji. Even though the table shows there is a word of extreme length $(7 \mathrm{moji})$ in the data, the formation of these four 
additional moji can be as simple as other patterns which only require minimum effort. At the same time, わんこ そば can be hit because of は is pronounced/wa/（わ) (i.e., there is no はんこそば /ha $\mathrm{n}$ ko so ba/ in their corpus). Therefore, simplicity in LP is a basic tendency and it can be done through different types of moji

Table 8. The length of word patterns in terms of the standard number of moji in terms of こんばんは

\begin{tabular}{lllll}
\hline & Syllable & & Kanji & \\
\cline { 2 - 4 } Number of moji & Frequency & Percentile & Frequency & Percentile \\
\hline $\mathrm{N}-1$ & 1 & $0.28 \%$ & 0 & $0.00 \%$ \\
$\mathrm{~N}$ & 321 & $89.66 \%$ & 21 & $80.77 \%$ \\
$\mathrm{~N}+1$ & 36 & $10.06 \%$ & 4 & $15.38 \%$ \\
$\mathrm{~N}+2$ & 0 & $0.00 \%$ & 0 & $0.00 \%$ \\
$\mathrm{~N}+3$ & 0 & $0.00 \%$ & 0 & $0.00 \%$ \\
$\mathrm{~N}+4$ & 0 & $0.00 \%$ & 1 & $3.85 \%$ \\
\hline
\end{tabular}

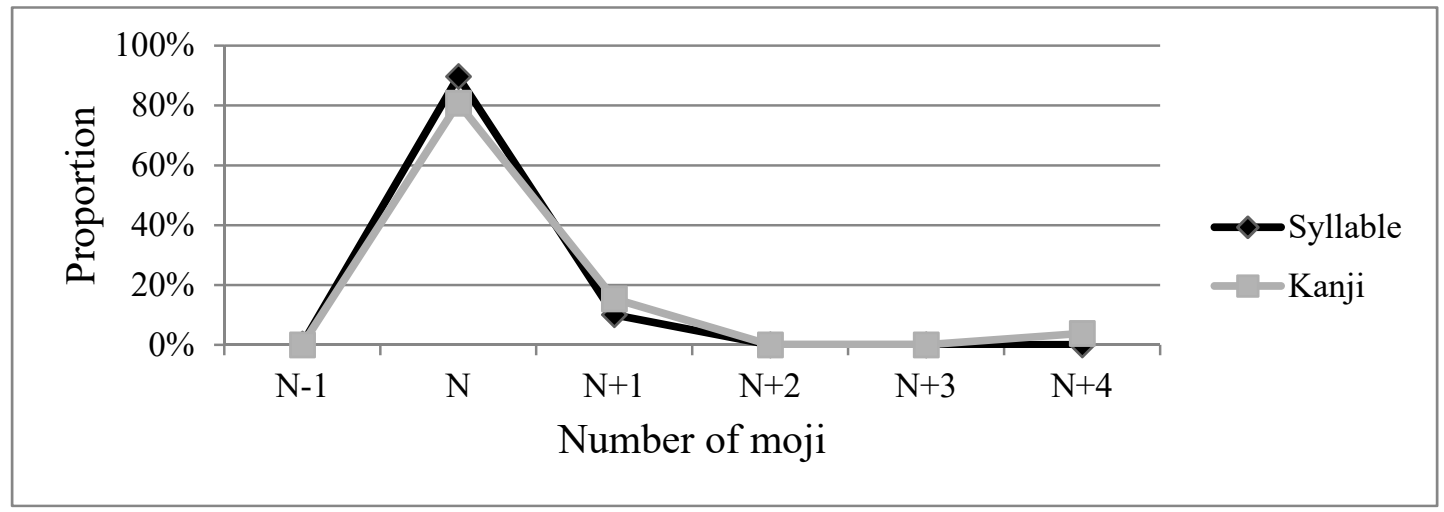

Figure 6. Percentile of length of each word pattern based on moji types in terms of こんばんは

Another replacement pattern unique to the こんばんは pattern is the replacement of the last syllable は(ha) withみ (mi) :こんばんみ. This is outside the word-addition rules seen in the previous examples including attachment of an additional vowel, long vowel marks, and methods which result in a sound pattern similar to the standard one. That is because this case has a different source:こんばんみ comes from the comedy material of a popular Japanese comedian called Bibil Ohki (ビビる大木). He is to a certain extent famous among Japanese comedians; many people are likely to have heard こんばんみ when viewing his TV program. In addition, his longtime use of this term shows that the sound of こんばんみis natural enough to be accepted by many Japanese, particularly young people. Therefore, it occurs in Keitai-mail as a frequent pattern, providing supporting evidence of social influence on language use.

\section{Conclusion}

Through these two case studies, it can be predicted that LP are creative acts based on standard forms using relatively simple methods without too much violation of the principle of naturalness to a native speaker of Japanese. Sounds, in particular the exact sounds as sensory information (such as the は of こんにちは/こんば んはbeing pronounced /wa/, which can be replaced by わ), have a relatively large impact on LP. Patterns where LP violates the natural sound expected in standard Japanese appear less frequently, and message creators are not likely to employ them.

\section{Acknowledgements}

This paper is based on my $\mathrm{PhD}$ dissertation (University of Queensland), would like to say thank you to my advisors: Emeritus Professor Nanette Gottlieb, Dr. Yuriko Naga, and Dr. Michael Harrington. This research project was supported by several scholarships and a research grant: The University of Queensland, the Faculty of Arts International Scholarship covered the tuition fees. A living allowance was provided by Nanette Gottlieb's Australian Professorial Fellowship, funded by the Australian Research Council. In addition, Tokyo Foundation also supported my data collection in Japan. I am thankful for these forms of financial support. 


\section{References}

Crystal, D. (2008). Txtng: The Gr8 Db8. Oxford: Oxford University Press.

Danet, B., \& Herring, S. C. (2007). Introduction: Welcome to the multilingual Internet. In B. Danet \& S. C. Herring (Eds.), The multilingual Internet: Language, culture, and communication online (pp. 3-39). Oxford: Oxford University Press.

Hanai, T., \& Oguchi, T. (2008). The appearance patterns of emotional expressions in e-mail exchanges: A text-mining analysis. Japanese Journal of Social Psychology, 24(2), 131-139. https://doi.org/10.14966/ jssp.KJ00005103412

Jungle. Inc. (2009) Keitai-master MX ver4.5 [Computer software].

Miller, L. (2004). Those naughty teenage girls: Japanese kogals, slang, and media assessments. Journal of Linguistic Anthropology, 14(2), 225-247. https://doi.org/10.1525/jlin.2004.14.2.225

Miyake, K. (2007). How young Japanese express their emotions visually in mobile phone messages: A sociolinguistic analysis. Japanese Studies, 27(1), 53-72. https://doi.org/10.1080/10371390701268646

Sakai, N. (2013).The role of sentence closing as an emotional marker: a case of Japanese mobile phone e-mail. Discourse, Context and Media, 2(3), 149-155. https://doi.org/10.1016/j.dcm.2013.07.001

Sakai, N. (2018). Social Differences in CMC: a Case Study of Japanese Mobile Phone E-mail. Journal of Technology in Behavioral Science, 3. https://doi.org/10.1007/s41347-018-0053-7

Zhao, S. (2006). Do Internet users have more social ties? A call for differentiated analyses of Internet use. Journal of Computer-Mediated Communication, 11(3), 844-862. https://doi.org/10.1111/j.1083-6101.2006. 00038.x

\section{Copyrights}

Copyright for this article is retained by the author(s), with first publication rights granted to the journal.

This is an open-access article distributed under the terms and conditions of the Creative Commons Attribution license (http://creativecommons.org/licenses/by/4.0/). 